\title{
CREATIVE ATTITUDES OF 6-GRADE PRIMARY SCHOOL PUPILS
}

\author{
Marzena Kielbasa \\ Państwowa Wyższa Szkoła Zawodowa w Nowym Sączu, Polska
}

\begin{abstract}
Teachers' recognition of the pupils' creative potential is far from easy because of the complexity, ambiguity and multifaceted quality of the phenomenon of creativity. The activity of diagnosing pupils' creative attitude calls for identifying the structure of their creative behaviour. Analysis of the data obtained in the study helped determine the level of the creative attitude of the pupils taking part in the study on the scale of heuristic and nonconformist behaviours.
\end{abstract}

Keywords: conformity, creative attitude, creative behaviour, heuristic behaviour, nonconformity, primary school.

\section{Introduction}

The present-day technology-oriented world needs creative individuals, capable of enriching this world with innovative, useful and valuable products. This is proved by the fact that the demand for enhancing pupils' creative attitudes in the process of school education is addressed by successive reformers of the education system in Poland and many other countries around the globe, as witnessed by the provisions of e.g. The Memphis Manifesto (Florida, 2010, p. 391-392), The Horizon Report K-12 - 2011, 2012, 2014, and in the Polish Core Curriculum of General Education (Journal of Laws of 2014, item 803). To carry out the above demand via pedagogical work in the school environment, it is vital do diagnose the creative potential of pupils, including the level of their creative attitude seen as "an active attitude towards the world and life, expressed in the drive to get to know and change both the external environment and oneself" (Popek, 2003, 23).

Teachers' recognition of the pupils' creative potential is far from easy because of the complexity, ambiguity and multifaceted quality of the phenomenon of creativity. The activity of diagnosing pupils' creative attitude calls for identifying the structure of their creative behaviour (Popek, 2010, 28). According to S. Popek, a creative attitude is composed of two zones: the cognitive one, constituted by algorithmic and heuristic activities located on a continuum and the emotional and motivational zone, determined by the continuum from conformity to non-conformity. 
The author of this article wants to present the results of a study on the creative attitude levels of 6-grade pupils of primary schools. Six-graders (12-13 years of age) are in a transition period of their creativity development, since they move from a conventional stage of a creative attitude (characterised also by an intense development of creative and evaluative competences, which constraints and hampers creativity) to a post-conventional stage, where despite the awareness of external limitations, they acquire an ability to produce novelty (Cropley, 1999, 514). For this reason, the author of this article assumes that diagnosing the creative attitude of pupils at this particular age and the implementation of adequate pedagogical practice may significantly enhance the process.

The study objective was to recognise and describe pupils' creative attitudes, taking into account the level of their creative behaviour on the scale of heuristic $(\mathrm{H})$ and non-conformist $(\mathrm{N})$ behaviour.

The study problem was formulated by means of the following question: What is the level of creative attitudes of 6-grade pupils of primary schools?

\section{Review of Earlier Relevant Research}

The question of a creative attitude in its many and varied aspects has been addressed, for example, by the following authors: S. Popek (Popek, 2000), H. Noga (Noga, 2013a, 2013b, 2014a, 2014b), I. Wysocka and A. Tokarz (Wysocka \& Tokarz, 2009), A. Tychmanowicz (Tychmanowicz, 2009), M. Kleszcz (Kleszcz, 2009), R. E. Bernacka (Bernacka 2009), R. E. Bernacka and E. Misiuda-Kolejko (Bernacka \& Kolejko, 2008).

S. Popek (2010) concluded in his research that pupils' creative attitude is manifested by their creative behaviour, which may be examined taking into account two functioning levels, i.e. the cognitive level and the characterological level (emotional and motivational). The cognitive level is characterised by heuristic behaviour: autonomy, activity, vitality, flexibility to adapt, originality, consistence, courage, dominance, self-organisation, spontaneity, expressiveness, openness, resilience and perseverance, responsibility, self-criticism, tolerance, and a high-self-esteem. The level of character is tied with non-conformist behaviour: autonomy of observation, logical memory, creative imagination, divergent thinking, reconstructive learning, autonomous learning, learning by comprehension, intellectual flexibility, cognitive activity, a high degree of reflexivity, intellectual self-sufficiency, creativity, high efficiency, constructive skills, verbal creativity, technical skills, and artistic aptitude. Because the above characteristics form a continuum, an examination may indicate a dominance of a specific type behaviour. According to Popek, characteristic of a creative personality is a dominance of heuristic and non-conformist over algorithmic and 
conformist behaviour, respectively. This is borne out by numerous scholars, e.g. S. Calshdan, G.S. Welsh, A. Strzałecki, R.S. Crutchfield, and S. Popek (after: Popek, 2010), who prove a link between non-conformity and creativity.

\section{Study Problem, Objectives and Methodology}

Since 2013, the author of the article, in collaboration with scholars from Constantine the Philosopher University in Nitra, has carried out research on the technical creativity of primary school pupils. This research has probed into the possibilities of developing pupils' technical creativity with the use of the educational project methodology. The first stage of the study process was the recognition of the creative attitudes of 6-grade primary school pupils, followed by an experimental implementation of an educational project for the development of these creative attitudes and the identification of changes in the behaviour of the pupils studied, triggered by the impact of this project.

In this article the author focuses on the presentation of results of a study of the creative attitudes of 6-grade pupils of primary schools.

\section{Study Methodology}

The study applied the standardised Creative Behaviour Questionnaire (Kwestionariusz Twórczego Zachowania $K A N H-I$ ). It is a tool applied in pedagogical and psychological research to diagnose creativity (seen as a permanent disposition to create innovative and valuable ideas) by means of a list of 60 statements related to various activities taking place in learning or performing an action. The tool can be used with older pupils, as of the age of 12 years. The person taking part in the study evaluates the statements on a threelevel scale as follows: true -2 points, partly true -1 point, false -0 points.

The raw data obtained during the study of the pupils are computed into stens. S. Popek's sten standards define creative attitudes on a three-level scale:

- $\quad$ between 1 and 4 stens - low level,

- $\quad$ between 5 and 6 stens - average level,

- $\quad$ between 7 and 10 stens - high level (Popek, 2010, 55, 79-81).

The study, taking place in November 2015, involved 197 pupils of 10 different six grades of primary schools in the city. The author was granted permission for conducing the studies with the application of the Creative Behaviour Questionnaire KANH-I by both the pupils and the principals of schools where the studies were carried out.

The study material was subject to a qualitative and quantitative analysis. 


\section{Data Analysis}

Analysis of the data obtained in the study helped determine the level of the creative attitude of the pupils taking part in the study on the scale of heuristic and non-conformist behaviours.

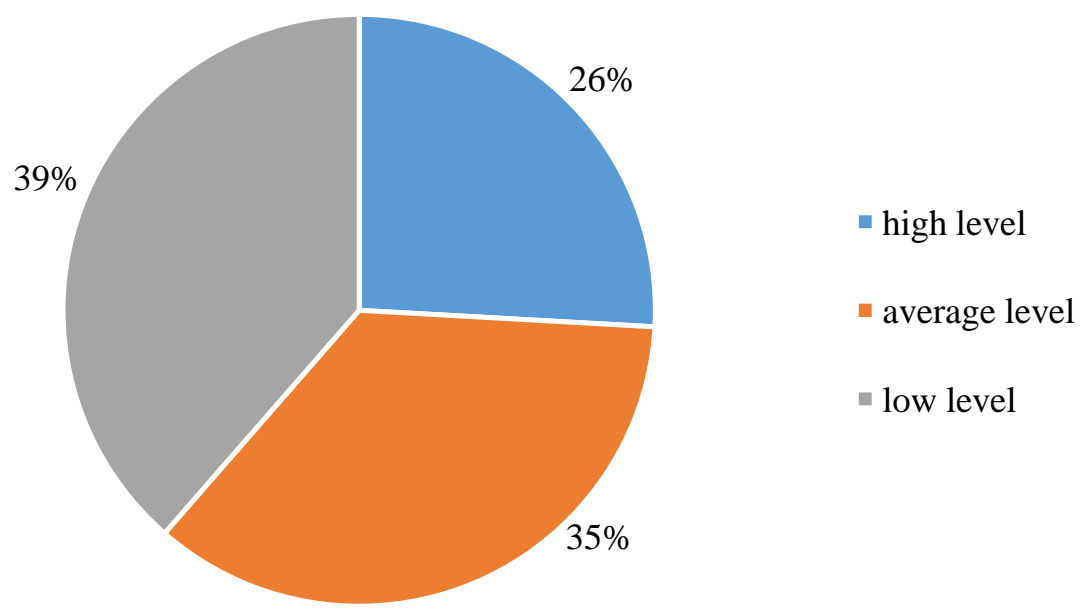

Figure 1 Percentage of pupils with a non-conformist attitude $(\mathbf{N}=197)$

Fig. 1. Shows the percentage of pupils with a non-conformist attitude on individual levels: $26 \%$ of the 6-graders studied demonstrate a high level of nonconformism, 35\% show an average level and 39\% - a low level.

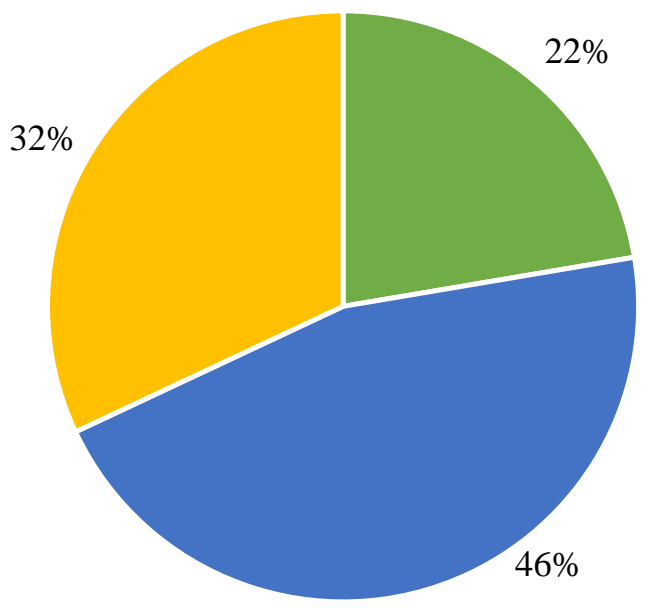

- high level

- average level

low level

Figure 2 Percentage of pupils with a heuristic attitude $(\mathbf{N}=197)$

Data concerning heuristic behaviour, percentage-wise, are shown in Fig. 2. Nearly half of the pupils studied (46\%) show an average level of heuristic behaviour, $32 \%-$ a low level and $22 \%$ - a high level. The pupils' results may indicate the level of their instrumental potential: perception skills, memory, 
processing and producing new information thanks to imagination, intuition and divergent thinking, all of which are of significance for creativity.

Table 1 Structure of pupils' creative attitudes by behaviour levels in percentage $(\mathbf{N}=197)$

\begin{tabular}{|l|c|c|c|}
\hline Nouristic behaviour & high level & $\begin{array}{c}\text { average } \\
\text { level }\end{array}$ & low level \\
\hline high level & $11.17 \%$ & $11.68 \%$ & $3.04 \%$ \\
\hline average level & $7.11 \%$ & $20.30 \%$ & $7.61 \%$ \\
\hline low level & $2.54 \%$ & $14.21 \%$ & $22.34 \%$ \\
\hline
\end{tabular}

Analysis of the results moreover helped determine the structure of the creative attitudes of the pupils studied, or the relation of demonstrated heuristic behaviour and non-conformist one (dominance or equilibrium). Data on the percentage of pupils with a particular structure of the creative attitude are shown in Table 1. Among the 6-graders studied, pupils with a low level of both heuristic and non-conformist behaviour constituted the highest percentage (22.34\%). $20.30 \%$ of pupils show an average level of both heuristic and nonconformist behaviour. A low level of heuristic behaviour and an attendant average level of non-conformist behaviour can be found in $14.21 \%$ of the pupils. A similar percentage of the pupils studied demonstrate a high level of heuristic behaviour and an attendant high level of non-conformist behaviour (11.17\%) as well as a high level of heuristic behaviour and an attendant average level of nonconformist behaviour (11.68\%). $7.11 \%$ of the pupils show an average level of heuristic behaviour and an attendant high level of non-conformist behaviour, while $7.61 \%$ have an average level of heuristic behaviour and a low level of non-conformist behaviour. The smallest percentage of the population examined are pupils with a high level of heuristic behaviour and an attendant low level of non-conformist behaviour (3.04\%) and pupils with a low level of heuristic behaviour and an attendant high level of non-conformist behaviour $(2.54 \%)$.

\section{Conclusions}

Summing up, the author presents conclusions arising from the study of the creative attitudes of 6-grade pupils of primary schools.

Analysis of the study results indicates that the highest percentage of pupils show a low level of non-conformist behaviour, which may be linked to an 
enhanced need for conformism when coming of age (Obuchowska, 1996) and the requirements of the school education, where "we are often required to be imitative and to behave the way other people do" (Noga, 2013, 85). Interestingly, a low level of non-conformist behaviour may hamper the use of the creative potential of the pupils studied. The results of studies of the heuristic attitude among 6-grade pupils demonstrate that nearly half of them (46\%) show an average instrumental potential. This group may be considered as prone to pedagogical influence in the cognitive zone.

Given the structure of pupils' creative attitude, the study discovered a high percentage of pupils with a low level of both heuristic and non-conformist behaviour. This means that these pupils have little instrumental potential and motivation for taking up creative action. According to the author, the potential of creative attitude development in this group of pupils calls for a further study.

Pupils with significant discrepancies between the level of heuristic and non-conformist behaviour may pose a challenge for educators. A high level of heuristic behaviour and an attendant low level of non-conformist behaviour indicates the pupils' high cognitive abilities but a very low motivation for creative action. This structure of the creative attitude may thwart the pupils' creative potential. In turn, pupils with a low level of heuristic behaviour and an attendant high level of non-conformist behaviour demonstrate high creative aspirations but lack the capacity, which may result in pathologies (Popek, 2010).

$11.17 \%$ of the pupils studied, characterised by a high level of both heuristic and non-conformist behaviour, is a group with the highest creative potential. Due to this potential, they should be subject to e.g. specialist creativity support programs.

Pupils with an average level of heuristic behaviour and non-conformist behaviour, i.e. $20.30 \%$ of the pupils studied, require the support of both their cognitive and characterological zones. Targeting pedagogical activities at these pupils might help them realise their creative potential.

Pedagogical work geared towards developing the characterological level of pupils with a high level of heuristic behaviour and an average non-conformist behaviour might result in an increase of their creative potential. In turn, pedagogical activities meant to develop the cognitive zone in pupils with an average level of heuristic behaviour and an attendant high level of nonconformist behaviour may impact the development of their creative attitudes.

Summing up, we may observe that the study results constitute a precious material for further research on the possibilities of developing pupils' creative attitudes, technological creativity included. 


\section{References}

Bernacka, E., R. (2009). Poznawcze i emocjonalno-motywacyjne różnice w funkcjonowaniu nonkonformistów konstruktywnych i pozornych. In: Popek, S. et al. (Eds.) Psychologia twórczości. Nowe horyzonty (pp. 176-182). Lublin: Wydawnictwo Uniwersytetu Marii Curie-Skłodowskiej.

Bernacka, E., R. (2008). Uczniowie zdolni nonkonformistyczni i konformistyczni a ich obraz siebie. In: Limont, W., Cieślikowski, J., Dreszer, J. (Eds.) Zdolności. Talent. Twórczość (pp.163-177). Toruń: Wydawnictwo Naukowe Uniwersytetu Mikołaja Kopernika.

Cropley, A. (1999). Definitions of Creativity. In: Runco, M. A., Pritzker, S. R. (Eds.) Encycklopedia of Creativity vol. 1 (pp. 511-524). San Diego: Academic Press Inc.

Kleszcz, M. (2009). Postawa twórcza jako wyznacznik systemu wartości młodzieży. In: Popek, S. et al. (Eds.) Psychologia twórczości. Nowe horyzonty (pp. 136-147). Lublin: Wydawnictwo Uniwersytetu Marii Curie-Skłodowskiej.

Kuśpit, M., Tychmanowicz, A. (2005). Poziom postawy twórczej uczniów o zróżnicowanym poziomie osiągnięć szkolnych. Annales Universitatiś Mariae Curie-Skłodowska Lublin - Polonia, XVIII, 60-69.

Nęcka, E. (2012). Psychologia twórczości. Sopot: Gdańskie Wydawnictwo Psychologiczne.

Noga, H. (2013). Postrzeganie rzeczywistości a postawy twórcze graczy komputerowych i osób niegrających. Edukacja - Technika - Informatyka, 4/2013, 79-85.

Noga, H., Vargová, M. (2013). Poziom postaw twórczych a uczestnictwo w technologii informacyjnej na przykładzie gier komputerowych. Annales Universitatis Paedagogicae cracoviensis. Studia Technica, VI/2013, 72-79.

Noga, H. (2014). Poziom postaw twórczych - analiza wybranych przypadków metodą Biofeedback. Edukacja - Technika - Informatyka, 5/2014, 503-508.

Noga, H. (2014). Senior citizens' creative attitude as a determinant of a life quality - research news. Edukacja Ustawiczna Dorostych, 1/2014, 19-26.

Pilch, T., Bauman, T. (2010). Zasady badań pedagogicznych. Warszawa: Wydawnictwo Akademickie „Żak”.

Popek, S. (2003). Człowiek jako jednostka twórcza. Lublin: Uniwersytet Marii CurieSkłodowskiej.

Popek, S. (2010). Kwestionariusz twórczego zachowania KANH. Lublin: Wydawnictwo UMCS.

Szmidt, K. J. (2007). Pedagogika twórczości. Gdańsk: Gdańskie Wydawnictwo Psychologiczne.

Tychmanowicz, A. (2009). Orientacje społeczne a postawa twórcza. In: Popek, S. et al. (Eds.) Psychologia twórczości. Nowe horyzonty (pp. 128-135). Lublin: Wydawnictwo Uniwersytetu Marii Curie-Skłodowskiej.

Wysocka, I., Tokarz, A. (2009). Dwa typy samooceny a postawy twórcze i zachowania twórcze młodzieży liceum ogólnokształcącego, plastycznego i ekonomicznego. In: Popek, S. et al. (Eds.) Psychologia twórczości. Nowe horyzonty (pp. 119-127). Lublin: Wydawnictwo Uniwersytetu Marii Curie-Skłodowskiej. 